\title{
PENGARUH PENGGUNAAN LUMPUR LIMBAH INDUSTRI PENYAMAKAN KULIT TERHADAP PENYERAPAN KROM PADA TANAMAN SAWI
}

\section{(THE EFFECT OF LEATHER TANNING INDUSTRY WASTE UTILIZATION ON CHROMIUM ADSORPTION OF GREEN MUSTARDS)}

\author{
A. R. Budi Darmawan \\ Fakultas Pertanian Universitas Lambung Mangkurat Banjarbaru \\ Email: arbd_99_05@yahoo.com \\ Diterima: 10 April 2011 \\ Direvisi: 20 April 2012 \\ Disetujui: 23 Mei 2012
}

\begin{abstract}
The aims of research was to study the effect of contaminated soil with tannery industrial wastesludge, and absorption level of chromium by the green mustard. The experiment was carried out in Kayen, Sleman, Yogyakarta for 3 months. The form of a pot experiment using a full factorial design $2 \times 3$ and 2 additional treatments as a control was set out in Completely Randomized Design (CRD), using 15 units of pots as replicates. The first factor consists of two varieties of mustard, which is kailan (chinesse kale) and spoon mustard greens (pak choy green). The second factor consists of 3 doses of leather tanning industry waste, i.e $500 \mathrm{mg}$ chromium $/ \mathrm{kg}$ soil, $1000 \mathrm{mg}$ chromium $/ \mathrm{kg}$ soil, $1500 \mathrm{mg}$ chromium $/ \mathrm{kg}$ soil. Control treatment was the planting of two varieties of mustard without the addition of sewage sludge. Preparation of sewage sludge was carried out by mixing the sewage sludge into the planting medium consisting of a mixture of soil, compost and manure treatments in accordance with the treatment. Observations made by harvesting the plants at the age of 3 and 6 weeks after planting for the next shoots and roots of plants and chromium content of growing media was analyzed. The results showed that the accumulation of chromium in the roots of plants was greater than in the plant canopy for the two types of mustards either good harvested at the age of 3 or 6 weeks after planting, and the content of chromium in plant tissues of mustard as part of vegetable that generally consumed exceeds the threshold of human daily consumption $(0,035 \mathrm{mg} / \mathrm{kg}$ daily consumption).
\end{abstract}

Keywords: chromium, leather tanning industrial waste, mustards

\begin{abstract}
ABSTRAK
Penelitian bertujuan untuk mempelajari pengaruh tanah yang terkontaminasi limbah industri penyamakan kulit terhadap sifat dan tingkat penyerapan krom pada tanaman sawi. Penelitian dilaksanakan di Kayen, Sleman, Daerah Istimewa Yogyakarta selama 3 bulan. Percobaan dengan pot menggunakan rancangan faktorial $2 \times 3$ lengkap dan 2 perlakuan tambahan sebagai kontrol yang diatur dalam Rancangan Acak Lengkap (RAL), dengan 15 unit pot sebagai ulangan percobaan. Faktor pertama terdiri atas 2 varietas sawi, yaitu kailan (chinesse kale) dan sawi sendok (pak choy green). Faktor kedua terdiri atas 3 aras takaran limbah industri penyamakan kulit, yaitu $500 \mathrm{mg}$ $\mathrm{krom} / \mathrm{kg}$ tanah, $1000 \mathrm{mg} \mathrm{krom} / \mathrm{kg}$ tanah, $1500 \mathrm{mg} \mathrm{krom} / \mathrm{kg}$ tanah. Perlakuan kontrol adalah penanaman 2 varietas sawi tanpa pemberian lumpur limbah. Pemberian limbah dilakukan dengan mencampur lumpur limbah ke dalam media tanam yang terdiri atas campuran tanah, kompos dan pupuk kandang sesuai dengan variasi perlakuan. Pengamatan dilakukan dengan memanen tanaman saat umur 3 dan 6 minggu setelah tanam untuk selanjutnya tajuk dan akar tanaman serta media tanam dianalisa kandungan kromnya. Hasil penelitian menunjukkan bahwa akumulasi krom di bagian perakaran tanaman lebih besar dibandingkan di bagian tajuk tanaman untuk kedua jenis sawi baik pada umur panen 3 maupun 6 minggu setelah tanam ternyata kandungan krom dalam jaringan tanaman sawi bagian tajuk yang lazim dikonsumsi melebihi ambang batas konsumsi harian manusia yang ditetapkan sebesar $0,035 \mathrm{mg} / \mathrm{kg}$ per hari.
\end{abstract}

Kata kunci: kromium, limbah industri penyamakan kulit, sawi 


\section{PENDAHULUAN}

Industri penyamakan kulit merupakan jenis industri yang menghasilkan limbah dan potensial menimbulkan masalah pencemaran. Proses pengolahan kulit, meski memberi nilai tambah besar pada kulit mentah, namun berpotensi menimbulkan pencemaran terhadap lingkungan karena penggunaan bahan-bahan kimia dalam prosesnya yang berpotensi membahayakan lingkungan. Apabila penggunaan bahan-bahan kimia tersebut tidak dibatasi dan dikelola dengan baik, akibatnya dapat mengancam keseimbangan lingkungan dan kesehatan manusia.

Lumpur limbah yang banyak mengandung krom akan mengganggu dan mencemari lingkungan apabila lumpur limbah tersebut tidak diolah ataupun dimanfaatkan. Pada beberapa industri penyamakan kulit lumpur limbahnya hanya ditampung dalam karung-karung plastik dan kemudian dibuang ke TPA (Tempat Pembuangan Akhir) atau dibuang di lahan yang digunakan untuk tempat pembuangan.

Pemanfaatan lahan tempat pembuangan lumpur limbah penyamakan kulit untuk usaha budidaya tanaman memiliki dampak yang merugikan karena besarnya kemungkinan akumulasi logam berat utamanya krom dalam tanah. Logam berat tersebut dapat ikut terserap oleh akar yang selanjutnya dibawa ke jaringan akar, batang, daun, buah atau biji tanaman sehingga bila masuk ke dalam rantai distribusi dan konsumsi pangan akan dapat meracuni manusia atau hewan yang mengkonsumsinya.

Terakumulasinya krom dalam jumlah besar di tubuh manusia jelas-jelas mengganggu kesehatan karena krom memiliki dampak negatif terhadap organ hati, ginjal serta bersifat racun bagi protoplasma makhluk hidup. Selain itu juga berdampak sebagai karsinogen (penyebab kanker), teratogen (menghambat pertumbuhan janin) dan mutagen (Chaney et al., USEPA, 2000 cit. Schiavon et al., 2008).

Lumpur industri penyamakan kulit biasanya mengandung kalsium (Ca) 10-30\%, nitrogen $(\mathrm{N}) 2-10 \%$, krom $(\mathrm{Cr}) 0,2-3 \%$, besi (Fe) $0-12 \%$ dan aluminium (Al) 0-6\% (jika garam fero dan aluminium digunakan untuk proses pengendapan) (Jun et al., 2009). Apabila $\mathrm{Cr}$ dalam lumpur terakumulasi di tanah dalam bentuk krom hidroksida, maka senyawa krom tersebut tidak larut dan bersifat toksik.

Telah dilaporkan bahwa $90 \%$ penyamakan kulit di dunia menggunakan senyawa krom. Persentase krom yang dibuang sebagai limbah cair dari sebuah industri penyamakan kulit mencapai $25 \%$ dari total limbah dengan konsentrasi 8.000 ppm (Saleh, 2007).

Pencemaran $\mathrm{Cr}$ valensi 6 dalam tingkat yang sangat tinggi $(14.600 \mathrm{mg} / \mathrm{kg}$ pada air tanah dan $25.900 \mathrm{mg} / \mathrm{kg}$ di tanah) dilaporkan di lokasi industri United Chrome Products, Corvallis, Oregon (Krishnamurthy dan Wilkens, 1994 cit. Ghani, 2011). Di India, sekitar 2.000-32.000 ton unsur Cr terbuang ke lingkungan setiap tahunnya dan itu berasal dari industri penyamakan kulit (Shanker et al., 2005)

Upaya membatasi limbah dapat dilakukan melalui pengurangan limbah pada sumbernya dan apabila mungkin dilakukan pemanfaatan limbah melalui cara penggunaan kembali (reuse), daur ulang (recycle), dan perolehan kembali (recovery).

Kromium adalah logam dengan jumlah terbanyak ketujuh yang ada di kerak bumi (Katz dan Salem, 1994 cit. Panda dan Choudhury, 2005) dan ditemukan di semua bagian dari lingkungan termasuk di udara, air dan tanah dalam jumlah yang wajar. Kisaran normal $\mathrm{Cr}$ di alam mulai dari 10 hingga 50 $\mathrm{mg} / \mathrm{kg}$ tergantung dari material induknya (Pandey dan Pandey, 2008 cit. Akinci dan Akinci, 2010).

Kromium tergolong mineral penting yang dibutuhkan dalam jumlah kecil (essential trace mineral) yang tidak dapat diproduksi oleh tubuh sehingga harus dipasok dari makanan sehari-hari. Zat ini sangat diperlukan bagi hampir semua jaringan tubuh manusia, termasuk kulit, otak, otot, limpa, ginjal dan testis. Kromium berperanan mengendalikan metabolisme insulin yang mengontrol kadar gula darah (sebagai glucose tolerance factor/GTF), membantu proses pencernaan protein dan lemak, menurunkan kadar trigliserid dan kolesterol darah. Tanaman telah menunjukkan kapasitas 
bertahan pada bahan kimia organik pada konsentrasi tinggi tanpa efek keracunan serta dapat mengambil dan mengubah bahan kimia tersebut secara cepat dan menjadi kurang toksik. Tanaman menstimulasi penurunan bahan kimia organik di rhizosfer dengan cara melepas eksudat akar, enzim dan penambahan karbon organik di tanah. Keberadaan kontaminan logam berat pada tanaman menunjukkan potensi untuk melakukan fitoekstraksi (penyerapan dan pemulihan kontaminan sampai diatas biomassa tanah), menyaring logam berat dari air melalui sistem perakaran (rhizofiltrasi), fitodegradasi (melakukan metabolisme kontaminan dengan bantuan enzim dalam jaringan tanaman), stabilisasi tempat pembuangan dengan mengontrol erosi dan evapotranspirasi air dalam jumlah besar (fitostabilisasi) dan penyerapan kontaminan serta melepasnya ke udara lewat daun (fitovolatilisasi) (Meuser, 2012).

Akumulasi Cr yang berbeda-beda pada bagian-bagian tanaman telah dilaporkan. Akar mengakumulasi 10-100 kali lebih banyak $\mathrm{Cr}$ dibanding tunas dan jaringan lainnya. Pada buncis, sedikitnya $0,1 \%$ dari total $\mathrm{Cr}$ yang berakumulasi ditemukan pada biji, sedangkan konsentrasi pada akar mencapai $98 \%$ dari total penyerapan Cr. Shallari et al. (1994) cit. Masdin (2010), yang mengumpulkan tanaman-tanaman yang ditanam di tanah yang mengandung garam tinggi (serpentin), dan menemukan bahwa Herniaria hirusta merupakan akumulator $\mathrm{Cr}$ yang tinggi. Selain itu tanaman air eceng gondok (Eichhornia crassipes) telah menunjukkan kapasitas yang tinggi untuk mengakumulasi $\mathrm{Cr}$ mencapai 6 $\mathrm{mg} /$ hari berat kering telah dideteksi pada akar tanaman ini yang tumbuh pada $10 \mathrm{ppm} \mathrm{Cr}$ valensi 6. Besarnya akumulasi Cr (160-350 $\mathrm{mg} \mathrm{Cr} / \mathrm{kg}$ berat kering pada akar dan mencapai 1,6-2,0 $\mathrm{mg} \mathrm{Cr} / \mathrm{kg}$ berat kering pada tunas) diamati untuk kol kembang, sayur hijau, dan cabe. Tanaman-tanaman tersebut diketahui sebagai spesies penyuka sulfur, tetapi tidak untuk kacang polong, strawberi, atau selada.

\section{BAHAN DAN METODE}

\section{Bahan penelitian}

Bahan-bahan penelitian terdiri atas benih sawi Kailan (Chinesse Kale) dan sawi sendok (Pak Choy Green) diperoleh dari PT. Sang Hyang Seri (Persero), pupuk kompos, tanah regosol (pasiran) sebagai media tumbuh tanaman, lumpur limbah dari Unit Pengolahan Air Limbah (UPAL) Balai Besar Kulit Karet dan Plastik, Sitimulyo, Yogyakarta.

\section{Alat Penelitian}

Alat penelitian meliputi cangkul, cetok, sabit, nampan pembibitan, polybag plastik kapasitas $5 \mathrm{~kg}$, mistar, timbangan, kertas label, alat tulis, gelas ukur, LI-COR leaf area meter tipe LI-3000 C, oven, alat pengukur $\mathrm{pH}$, Atomic Absorbtion Spectrofotometer (AAS) tipe AA-100 single beam.

\section{Cara Penelitian}

Penelitian dilakukan di Kabupaten Sleman, Daerah Istimewa Yogyakarta berupa percobaan pot menggunakan rancangan faktorial $2 \times 3$ lengkap dan 2 perlakuan tambahan sebagai kontrol yang diatur dalam Rancangan Acak Lengkap (RAL), dengan 15 unit pot sebagai ulangan. Penelitian dilakukan mulai bulan Desember 2008 s/d Februari 2009.

Faktor pertama terdiri atas 2 varietas sawi, yaitu:

$\mathrm{S} 1=$ Kailan/Chinesse Kale (Brassica oleracea var. alboglabra)

$\mathrm{S} 2=$ Sawi sendok/Pak Choy Green (Brassica campestris var. chinensis)

Faktor kedua terdiri atas 3 aras takaran limbah

$\mathrm{L} 2=500 \mathrm{mg} \mathrm{krom} / \mathrm{kg}$ tanah (setara dengan 25 g lumpur limbah/kg media tanah)

$\mathrm{L} 3=1000 \mathrm{mg} \mathrm{krom} / \mathrm{kg}$ tanah (setara dengan $50 \mathrm{~g}$ lumpur limbah/kg media tanah)

$\mathrm{L} 4=1500 \mathrm{mg} \mathrm{krom} / \mathrm{kg}$ tanah (setara dengan $75 \mathrm{~g}$ lumpur limbah/kg media tanah)

Sebagai pembanding perlakuan, dibuat kontrol untuk masing-masing jenis sawi yaitu dengan menanam sawi tanpa diberikan tambahan lumpur limbah ke dalam media tanam dengan kode S1L1 dan S2L1.

Tabel 1. Rancangan percobaan pemberian perlakuan lumpur limbah

\begin{tabular}{ccccc}
\hline \multirow{2}{*}{ Jenis sawi } & \multicolumn{4}{c}{ Takaran limbah $(\mathrm{mg} \mathrm{Cr} / \mathrm{kg}$ tanah) } \\
\cline { 2 - 5 } & 0 & 500 & 1000 & 1500 \\
\hline Kailan & S1L1 & S1L2 & S1L3 & S1L4 \\
Pakchoy & S2L1 & S2L2 & S2L3 & S2L4 \\
\hline
\end{tabular}


Penentuan takaran lumpur limbah diatas berdasarkan hasil analisa lumpur limbah menggunakan AAS yang menunjukkan bahwa dalam setiap kg lumpur limbah mengandung krom sebesar $19.985 \mathrm{mg}$, dengan demikian perhitungan takaran dilakukan memakai rumus :

$\mathrm{L} 2=500 \mathrm{mg} \mathrm{krom} / \mathrm{kg}$ tanah $=500 \mathrm{mg} / 19.985$ mg x $1 \mathrm{~kg}$ lumpur limbah $=0,025 \mathrm{~kg}=25$ $\mathrm{g}$ lumpur limbah. Sehingga lumpur limbah yang diberikan ke media tanam (tanaman) untuk tiap polybag volume 5 $\mathrm{kg}$ sebesar $=25 \mathrm{~g} \mathrm{x} 5=125 \mathrm{~g}$ lumpur limbah.

$\mathrm{L} 3=1000 \mathrm{mg} \mathrm{krom} / \mathrm{kg}$ tanah $=1000 \mathrm{mg} /$ $19.985 \mathrm{mg} x 1 \mathrm{~kg}$ lumpur limbah = 0,05 $\mathrm{kg}=50 \mathrm{~g}$ lumpur limbah. Sehingga lumpur limbah yang diberikan ke media tanam (tanaman) untuk tiap polybag volume $5 \mathrm{~kg}$ sebesar $=50 \mathrm{~g}$ × $5=250 \mathrm{~g}$ lumpur limbah.

$\mathrm{L} 4=1500 \mathrm{mg} \mathrm{krom} / \mathrm{kg}$ tanah $=1500 \mathrm{mg} /$ $19.985 \mathrm{mg}$ x $1 \mathrm{~kg}$ lumpur limbah =0,075 $\mathrm{kg}=75 \mathrm{~g}$ lumpur limbah. Sehingga lumpur limbah yang diberikan ke media tanam (tanaman) untuk tiap polybag volume $5 \mathrm{~kg}$ sebesar $=75 \mathrm{~g}$ x $5=375 \mathrm{~g}$ lumpur limbah.

\section{Pemberian Perlakuan}

Pemberian kontaminan limbah industri penyamakan kulit dilaksanakan dengan cara memberikan lumpur limbah kedalam polybag media tanam sesuai dengan perlakuan yang telah direncanakan pada saat bibit dipindah ke polybag tanam

\section{Pemanenan}

Pemanenan dilakukan setelah tanaman berumur 3 minggu dari waktu tanam (panen awal atau panen korban) dan 6 minggu setelah tanam (panen akhir). Pemanenan dilakukan dengan mengambil 5 tanaman sebagai sampel untuk tiap kombinasi perlakuan pada panen awal dan 10 sampel tanaman pada panen akhir.

\section{Analisis tanah dan tanaman}

- Analisis media tanam sebelum perlakuan, meliputi : Kadar lengas (\%), pH, C total $(\%), \mathrm{N}$ total $(\%)$, Bahan organik $(\%), \mathrm{P}$ tersedia ( $\mathrm{ppm}), \mathrm{K}$ tersedia (ppm), rasio $\mathrm{C} / \mathrm{N}, \mathrm{Cr}$ total (ppm)
- Analisis media tanam sesudah perlakuan, meliputi : Kadar lengas (\%), pH, C total $(\%), \mathrm{N}$ total $(\%)$, Bahan organik $(\%), \mathrm{P}$ tersedia (ppm), $\mathrm{K}$ tersedia (ppm), rasio $\mathrm{C} / \mathrm{N}, \mathrm{Cr}$ total (ppm)

- Analisis media tanam sesudah panen, meliputi :Kadar lengas (\%), pH, C total $(\%), \mathrm{N}$ total $(\%)$, Bahan organik $(\%), \mathrm{P}$ tersedia (ppm), $\mathrm{K}$ tersedia (ppm), rasio $\mathrm{C} / \mathrm{N}, \mathrm{Cr}$ total (ppm)

- Analisis kandungan limbah, meliputi : $\mathrm{Cr}$ total, $\mathrm{pH}$

- Analisis jaringan tanaman, meliputi : $\mathrm{Cr}$ dalam tajuk dan akar

Analisis dilakukan di Laboratorium Pangan dan Hasil Pertanian, Fakultas Teknologi Pertanian, Universitas Gadjah Mada menggunakan alat AAS.

\section{HASILDAN PEMBAHASAN}

\section{Komponen media tanam awal dan limbah industri penyamakan kulit}

Media tanam yang digunakan dalam penelitian terdiri atas campuran tanah, kompos dan pasir dengan perbandingan 1:1:1. Jenis tanah dalam media tanam termasuk regosol yang secara umum mempunyai sifatsifat (Anonim, 2010) : mengandung bahanbahan yang belum atau baru mengalami pelapukan, tekstur tanah kasar, struktur remah, konsistensi lepas-lepas sampai gembur dan $\mathrm{pH}$ berkisar 6-7. Jenis tanah ini lemah dalam pembentukan agregat sehingga peka terhadap erosi dan lolos air, cukup mengandung unsur fosfat dan kalium yang masih segar dan belum diserap tanaman serta memiliki kapasitas tukar kation relatif kecil. Analisis terhadap media tanam yang dilakukan sebelum pemberian limbah bertujuan untuk mengetahui tingkat kesuburan awal, kandungan unsur hara makrodan ada atau tidaknya kandungan kromium (Cr) pada media tanam. Hasil analisis menunjukkan bahwa kandungan $\mathrm{N}$ total sedang, kandungan $\mathrm{P}$ dan $\mathrm{K}$ tinggi, kadar $\mathrm{C}$-organik tinggi, nisbah $\mathrm{C} / \mathrm{N}$ tinggi, bahan organik tinggi dan $\mathrm{pH}$ tanah netral. Hasil analisis juga menunjukkan bahwa dalam media tanam terdapat unsur $\mathrm{Cr}$ dengan konsentrasi rendah (Tabel 2). Keberadaan unsur $\mathrm{Cr}$ dalam media tanam dimungkinkan 
karena secara alamiah $\mathrm{Cr}$ ditemukan dalam konsentrasi yang rendah pada batuan, tanah, debu vulkanik dan gas di udara dalam beberapa bentuk senyawa yang berbeda (semisal krom sulfat, krom oksida, krom klorida, kalsium kromat, natrium dikromat dan seng kromat). Selain itu, terdeteksinya $\mathrm{Cr}$ dalam media tanam dapat disebabkan tanah yang digunakan untuk media tanam adalah tanah kebun yang diduga pernah menjadi tempat pembuangan berbagai macam sampah atau $\mathrm{Cr}$ tersebut berasal dari pupuk kompos yang digunakan sebagai campuran media tanam.

Tabel 2. Hasil analisis media tanam sebelum perlakuan

\begin{tabular}{lcc}
\hline \multicolumn{1}{c}{ Variabel } & Media Tanam & Harkat $^{(*)}$ \\
\hline $\mathrm{N}$ total $(\%)$ & 0,412 & Sedang \\
$\mathrm{P}_{2} \mathrm{O}_{5}(\mathrm{ppm})$ & 1.358 & Tinggi \\
$\mathrm{K}_{2} \mathrm{O}(\mathrm{ppm})$ & 1.728 & Tinggi \\
$\mathrm{Cr}(\mathrm{ppm})$ & 3,457 & Rendah \\
$\mathrm{C}$ organik $(\%)$ & 14,07 & Tinggi \\
$\mathrm{C} / \mathrm{N}$ rasio & 34,15 & Tinggi \\
pH $\mathrm{H}_{2} \mathrm{O}$ & 6,61 & Netral \\
Bahan Organik (\%) & 24,25 & Tinggi \\
\hline
\end{tabular}

${ }^{\left({ }^{(*)}\right.}$ Harkat menurut Laboratorium Teknologi Pangan dan Hasil Pertanian FTP UGM

Analisis terhadap limbah dilakukan untuk mengetahui kandungan-kandungan unsur yang ada termasuk kadar kromium. Hasil analisis kadar kromium dalam limbah dijadikan dasar untuk menentukan takaran limbah yang diberikan kepada media tanam sesuai perlakuan. Tabel 3 menunjukkan bahwa kadar krom limbah industri penyamakan kulit sangat tinggi (19.985 ppm), sehingga berpotensi sangat besar mencemari lingkungan dan membahayakan kesehatan bila masuk ke dalam tubuh manusia melalui rantai makanan.

Selain mengandung krom dengan kadar sangat tinggi, limbah industri penyamakan kulit juga mengandung unsur $\mathrm{N}, \mathrm{P}$, dan $\mathrm{K}$ tinggi, $\mathrm{C}$-organik tinggi, nisbah $\mathrm{C} / \mathrm{N}$ tinggi, kadar bahan organik tinggi dan $\mathrm{pH}$ agak masam sehingga lumpur limbah tersebut berpotensi dimanfaatkan sebagai media tanam yang baik setelah kadar kromnya diturunkan pada ambang batas yang rendah.
Tabel 3. Hasil analisis limbah penyamakan kulit

\begin{tabular}{|l|c|c|}
\hline \multicolumn{1}{|c|}{ Variabel } & Limbah & Harkat $^{\left({ }^{*}\right)}$ \\
\hline $\mathrm{N}$ total $(\%)$ & 1,498 & Tinggi \\
$\mathrm{P}_{2} \mathrm{O}_{5}(\mathrm{ppm})$ & 1.853 & Tinggi \\
$\mathrm{K}_{2} \mathrm{O}(\mathrm{ppm})$ & 1.611 & Tinggi \\
$\mathrm{Cr}($ ppm) & 19.985 & Sangat tinggi \\
$\mathrm{C}$ organik (\%) & 44,60 & Tinggi \\
$\mathrm{C} / \mathrm{N}$ rasio & 29,77 & Tinggi \\
pH $\mathrm{H}_{2} \mathrm{O}$ & 6,05 & Agak masam \\
Bahan Organik (\%) & 21,68 & Tinggi \\
\hline
\end{tabular}

${ }^{(*)}$ Harkat menurut Laboratorium Teknologi Pangan dan Hasil Pertanian FTP UGM

\section{Komponen media tanam setelah pemberian perlakuan}

Analisis media tanam yang dilakukan setelah perlakuan (Tabel 4) dibandingkan dengan analisis media tanam setelah panen akhir sawi (panen kedua) untuk mengetahui besarnya penyerapan kromium oleh tanaman dan kehilangan kromium dari media tanam setelah panen sawi dilakukan.

Tabel 4. Kandungan krom (ppm) dalam media tanam setelah perlakuan

\begin{tabular}{lc}
\hline \multicolumn{1}{c}{ Perlakuan } & Kandungan Cr (ppm) \\
\hline Tanpa penambahan limbah & 3,457 \\
$500 \mathrm{mg} \mathrm{Cr} / \mathrm{kg}$ media tanam (125 g) & 498,159 \\
$1000 \mathrm{mg} \mathrm{Cr} / \mathrm{kg}$ media tanam $(250 \mathrm{~g})$ & $1.025,13$ \\
$1500 \mathrm{mg} \mathrm{Cr} / \mathrm{kg}$ media tanam $(375 \mathrm{~g})$ & $1.491,0$ \\
\hline
\end{tabular}

Hasil analisis menunjukkan jika makin tinggi penambahan lumpur limbah industri penyamakan kulit ke dalam polybag media tanam yakni mulai $125 \mathrm{~g}$, $250 \mathrm{~g}$ sampai dengan $375 \mathrm{~g}$, maka akan memberikan peningkatan kandungan krom dalam media tanam sebesar berturut-turut 498,159 ppm; 1.025,13 ppm dan $1.491 \mathrm{ppm}$. Hal ini menunjukkan bahwa makin banyak timbunan lumpur limbah penyamakan kulit yang dibuang ke lahan akan menyebabkan pencemaran yang berat dengan tingginya kadar krom di lahan tersebut.

\section{Hasil analisis krom dalam tanaman dan media tanam setelah panen}

Hasil analisis kandungan krom dalam jaringan tanaman diperlukan untuk 
mengetahui besarnya krom yang dapat diserap tanaman dan terakumulasi di berbagai bagian tanaman saat pertumbuhan tanaman masih berlangsung cepat maupun saat panen akhir dilakukan. Analisis unsur krom yang dilakukan terhadap media tanam tempat tanaman tumbuh sebelumnya juga penting dilakukan untuk mengetahui sisa krom yang masih ada di media tanam dan hilangnya krom ke lingkungan akibat terlindi saat penyiraman dilakukan.

\subsection{Hasil analisis krom dalam tanaman 3 minggu setelah tanam (mst)}

Hasil analisis krom dalam jaringan tanaman saat panen awal (Tabel 5) menunjukkan bila jumlah krom yang terkandung di bagian perakaran tanaman lebih besar dibanding bagian tajuk baik pada kailan maupun pakchoy.

Hal ini karena akar merupakan bagian tanaman yang berfungsi menyerap unsurunsur dalam tanah termasuk krom lalu mentranslokasikan ke bagian tanaman yang lain.
Disamping itu krom akan diserap oleh tanaman melalui sistem perakaran secara relatif cepat namun ditranslokasikan ke bagian tajuk (daun) dengan lambat (Akinci dan Akinci, 2010). Penyerapan kromium yang cepat dipengaruhi pula oleh dikeluarkannya eksudat akar yang mengandung asam organik. Asam organik ini dapat membentuk hubungan dengan senyawa krom dan membuatnya tersedia untuk diserap tanaman (Bartlett dan James, 1988 cit. Panda dan Choudhury, 2005).

Persentase penyerapan krom semakin meningkat pada kailan dan pakchoy seiring pertambahan takaran limbah. Adanya kandungan unsur hara dan bahan organik yang besar memberi pengaruh yang signifikan terhadap pertumbuhan tanaman sehingga proses metabolisme tanaman termasuk penyerapan unsur-unsur di dalam tanah juga cepat. Kailan menyerap krom lebih banyak dibanding pakchoy dikarenakan fisik morfologis tanaman yang lebih besar sehingga bagian perakarannya juga lebih besar dan banyak. Perakaran ini penting untuk menunjang tegaknya tajuk.

Tabel 5. Hasil analisis krom dalam tanaman $3 \mathrm{mst}$

\begin{tabular}{|c|c|c|c|c|c|c|}
\hline \multirow[t]{2}{*}{ Perlakuan } & \multicolumn{3}{|c|}{ Kandungan krom (ppm) } & \multicolumn{3}{|c|}{$\begin{array}{l}\text { Persentase penyerapan kandungar } \\
\text { krom dari media tanam }(\%)\end{array}$} \\
\hline & Tajuk & Akar & Total & Tajuk & Akar & Total \\
\hline $\begin{array}{l}\text { Kailan } \\
0 \mathrm{mg} / \mathrm{kg}\end{array}$ & 0,991 & 2,466 & 3,457 & 28,66 & 71,33 & 100 \\
\hline $\begin{array}{l}\text { Kailan } \\
500 \mathrm{mg} / \mathrm{kg}\end{array}$ & 2,823 & 16,010 & 18,83 & 0,56 & 3,21 & 3,77 \\
\hline $\begin{array}{l}\text { Kailan } \\
1000 \mathrm{mg} / \mathrm{kg}\end{array}$ & 4,486 & 49,623 & 54,109 & 0,43 & 4,84 & 5,27 \\
\hline $\begin{array}{c}\text { Kailan } \\
1500 \mathrm{mg} / \mathrm{kg}\end{array}$ & 7,734 & 79,044 & 86,778 & 0,51 & 5,30 & 5,82 \\
\hline $\begin{array}{l}\text { Pakchoy } \\
0 \mathrm{mg} / \mathrm{kg}\end{array}$ & 2,544 & 0,913 & 3,457 & 73,58 & 26,41 & 100 \\
\hline $\begin{array}{l}\text { Pakchoy } \\
500 \mathrm{mg} / \mathrm{kg}\end{array}$ & 3,831 & 5,892 & 9,723 & 0,76 & 1,18 & 1,95 \\
\hline $\begin{array}{l}\text { Pakchoy } \\
1000 \mathrm{mg} / \mathrm{kg}\end{array}$ & 11,663 & 41,767 & 53,43 & 0,78 & 2,80 & 3,58 \\
\hline $\begin{array}{l}\text { Pakchoy } \\
1500 \mathrm{mg} / \mathrm{kg}\end{array}$ & 7,334 & 30,683 & 38,017 & 0,71 & 2,99 & 3,70 \\
\hline
\end{tabular}




\subsection{Hasil analisis krom dalam tanaman 6 minggu setelah tanam (mst)}

Persentase kromium total dalam jaringan tanaman 6 mst lebih besar dibanding 3 mst (Tabel 6). Hal ini berarti bahwa sampai dengan panen akhir dilakukan, metabolisme tanaman masih tetap berjalan meski terdapat kecenderungan sampai dengan pemberian takaran limbah $1000 \mathrm{mg} / \mathrm{kg}$ merupakan titik kritis tanaman dapat tumbuh dan berkembang tanpa dipengaruhi oleh krom dalam limbah secara nyata.

Kandungan krom di bagian perakaran lebih besar dibanding bagian tajuk untuk perlakuan pemberian limbah, tetapi hal sebaliknya terjadi pada perlakuan tanpa pemberian limbah. Penyerapan krom semakin lambat dengan semakin besarnya takaran limbah yang diberikan pada kailan dan pakchoy. Hal ini menunjukkan bahwa tanaman mengakumulasi lebih banyak kontaminan di lingkungan pertanamannya pada konsentrasi polutan yang kecil dan kemampuan penyerapan unsur kontaminan semakin menurun pada kondisi konsentrasi polutan yang makin besar.

Konsentrasi kromium dalam jaringan tanaman berhubungan dengan gejala toksisitas dan biasanya memiliki kisaran beberapa ratus ppm. Rentang kadar krom yang tinggi dalam jaringan tanaman sebelum gejala keracunan teramati berkisar antara 5 ppm pada barley, oat, jagung dan jeruk hingga 175 ppm pada tembakau (Sinha et al., 2005 cit. Akinci dan Akinci, 2010). Hal inilah yang menyebabkan terhentinya serapan krom oleh sawi yang dijadikan tanaman uji. Kailan dan pakchoy masih menyerap krom dalam jumlah besar pada takaran $1000 \mathrm{mg} / \mathrm{kg}$ dengan jumlah serapan 126,389 ppm dan 61,781 ppm; namun serapan krom makin turun dengan bertambahnya takaran limbah.

Moral et al (1995) cit. Ghani (2011) menyatakan bahwa peningkatan konsentrasi krom dalam tanah menurunkan kandungan $\mathrm{N}$, $\mathrm{P}, \mathrm{K}, \mathrm{Ca}$ dan $\mathrm{Fe}$ pada sistem perakaran Brasssica juncea. Penghambatan penyerapan unsur hara tersebut dikarenakan adanya kompetisi dengan $\mathrm{Cr}$ yang terserap akar. Pada konsentrasi $\mathrm{Cr}$ tinggi dimana akar yang tercekam diamati, pengurangan penyerapan unsur hara esensial tersebut mungkin disebabkan rusaknya fungsi membran tanaman.

Tabel 6. Hasil analisis krom dalam tanaman 6 mst

\begin{tabular}{ccccccc}
\hline Perlakuan & \multicolumn{3}{c}{ Kandungan krom (ppm) } & \multicolumn{3}{c}{$\begin{array}{c}\text { Persentase penyerapan kandungan } \\
\text { krom dari media tanam }(\%)\end{array}$} \\
\cline { 2 - 7 } & Tajuk & Akar & Total & Tajuk & Akar & Total \\
\hline $\begin{array}{c}\text { Kailan } \\
0 \mathrm{mg} / \mathrm{kg}\end{array}$ & 2,275 & 1,182 & 3,457 & 65,80 & 34,19 & 100 \\
$\begin{array}{c}\text { Kailan } \\
500 \mathrm{mg} / \mathrm{kg}\end{array}$ & 3,984 & 38,922 & 42,906 & 0,79 & 7,81 & 8,61 \\
$\begin{array}{c}\text { Kailan } \\
1000 \mathrm{mg} / \mathrm{kg}\end{array}$ & 21,941 & 104,448 & 126,389 & 1,47 & 7,00 & 8,47 \\
$\begin{array}{c}\text { Kailan } \\
1500 \mathrm{mg} / \mathrm{kg}\end{array}$ & 3,634 & 63,826 & 67,46 & 0,35 & 6,22 & 6,58 \\
$\begin{array}{c}\text { Pakchoy } \\
0 \mathrm{mg} / \mathrm{kg}\end{array}$ & 1,952 & 1,505 & 3,457 & 56,46 & 43,53 & 100 \\
$\begin{array}{c}\text { Pakchoy } \\
500 \mathrm{mg} / \mathrm{kg}\end{array}$ & 4,378 & 20,647 & 25,025 & 0,87 & 4,14 & 5,02 \\
$\begin{array}{c}\text { Pakchoy } \\
1000 \mathrm{mg} / \mathrm{kg} \\
\text { Pakchoy }\end{array}$ & 9,449 & 52,332 & 61,781 & 0,63 & 3,50 & 4,14 \\
$1500 \mathrm{mg} / \mathrm{kg}$ & 7,258 & 33,766 & 41,024 & 0,70 & 3,29 & 4,00 \\
\hline
\end{tabular}




\section{Hasil analisis krom dalam media tanam setelah panen}

Hasil analisis kadar krom yang tersisa dalam media tanam (Tabel 7) menunjukkan bahwa sisa krom dalam media tanam masih sangat tinggi. Apabila tanah dalam media tanam digunakan kembali untuk budidaya tanaman terutama sawi, maka masih banyak krom yang dapat diserap oleh jaringan tanaman dan terakumulasi pada bagian-bagian yang dikonsumsi manusia. Jika pada percobaan pot menghasilkan sisa kandungan krom di media tanam yang masih tinggi, maka hal yang sama dapat berlaku pada tempat pembuangan limbah industri penyamakan kulit dimana akumulasi krom di lahan kemungkinan lebih besar dibanding dalam media tanam polybag. Hal ini dikarenakan luasan lahan yang lebih luas dan efek penyiraman serta limpasan air hujan yang lebih kecil. Persentase krom yang hilang akibat terlindi bersama air penyiraman ataupun limpasan akibat air hujan cukup besar, berkisar antara $16 \%$ hingga $46 \%$. Hilangnya krom ini menjadikan konsentrasinya dalam media tanam menjadi lebih kecil sehingga efek toksisitasnya menjadi lebih kecil pula dan memungkinkan tanaman masih dapat bertahan tumbuh meski diduga gejala-gejala penghambatan pertumbuhan tanaman telah terjadi akibat adanya cekaman (stress) krom.
Berdasarkan hasil analisis jaringan tanaman, penyerapan krom oleh kedua jenis sawi menunjukkan jika akumulasi krom dalam tajuk tanaman yang umumnya dikonsumsi telah melebihi konsumsi ambang batas harian sebesar $0,035 \mathrm{mg} / \mathrm{kg}$ per hari bagi orang dewasa. Kadar krom yang tinggi di jaringan tanaman hasil penelitian ini, terutaman yang terdapat pada perakaran tanaman sawi dapat menjadi sumber pencemar potensial bagi lingkungan bila dikembalikan langsung ke dalam tanah baik secara langsung (ditimbun atau dibuang ke lahan) maupun diolah menjadi pupuk kompos.

Beberapa usaha lain yang mungkin dapat dilakukan adalah dengan mengolah bagian tanaman dengan kadar krom tinggi menjadi barang lain yang tidak dikonsumsi seperti hasilnya sebagai campuran ataupun filler (bahan pengisi) dalam pembuatan batu bata, leatherboard, ataupun dengan mengekstrak bagian akar tanaman untuk mendapatkan unsur krom yang dapat digunakan kembali dalam proses penyamakan kulit.

Penerapan cara yang cepat dan berbiaya murah untuk mengatasi pencemaran logam berat seperti kromium di areal pertanian yang luas mutlak diperlukan. Karena proses pembersihan secara tradisional biayanya mahal dan praktis hanya di area yang kecil.

Tabel 7. Hasil analisis krom dalam media tanam setelah panen

\begin{tabular}{|c|c|c|c|c|}
\hline \multirow[t]{2}{*}{ Perlakuan } & \multicolumn{3}{|c|}{ Kandungan krom (ppm) } & \multirow{2}{*}{$\begin{array}{l}\text { Persentase total } \\
(\%)\end{array}$} \\
\hline & Media tanam & Tanaman & Total & \\
\hline $\begin{array}{c}\text { Kailan } \\
0 \mathrm{mg} / \mathrm{kg}\end{array}$ & - & 3,457 & 3,457 & 100 \\
\hline $\begin{array}{c}\text { Kailan } \\
500 \mathrm{mg} / \mathrm{kg}\end{array}$ & 258,470 & 42,906 & 301,376 & 60,49 \\
\hline $\begin{array}{c}\text { Kailan } \\
1000 \mathrm{mg} / \mathrm{kg}\end{array}$ & 427,087 & 126,389 & 553,476 & 53,99 \\
\hline $\begin{array}{c}\text { Kailan } \\
1500 \mathrm{mg} / \mathrm{kg}\end{array}$ & 988,023 & 67,46 & 1055,483 & 70,79 \\
\hline $\begin{array}{l}\text { Pakchoy } \\
0 \mathrm{mg} / \mathrm{kg}\end{array}$ & - & 3,457 & 3,457 & 100 \\
\hline $\begin{array}{c}\text { Pakchoy } \\
500 \mathrm{mg} / \mathrm{kg}\end{array}$ & 260,249 & 25,025 & 285,274 & 57,26 \\
\hline $\begin{array}{c}\text { Pakchoy } \\
1000 \mathrm{mg} / \mathrm{kg}\end{array}$ & 523,522 & 61,781 & 585,303 & 57,09 \\
\hline $\begin{array}{c}\text { Pakchoy } \\
1500 \mathrm{mg} / \mathrm{kg}\end{array}$ & 1206,563 & 41,024 & 1247,587 & 83,67 \\
\hline
\end{tabular}


Kegiatan untuk membersihkan tanah yang tercemar tersebut biasanya ditempuh dengan cara remediasi, baik secara in-situ (onsite/pembersihan di lokasi) ataupun ex-situ (off-site). Penelitian-penelitian yang dilakukan untuk menemukan metode baru yang efektif dan berbiaya murah diantaranya dengan menggunakan mikroorganisme, biomassa dan tanaman hidup sebagai akumulator logam berat (Peralta et al., 2001 cit. Akinci dan Akinci, 2010). Tanaman yang ideal yang akan digunakan untuk fitoremediasi harus memiliki produktivitas biomassa tinggi, umur pendek, toleransi yang tinggi, mudah dikelola, dapat tumbuh di berbagai lokasi serta kapasitas akumulasi konsentrasi tinggi dari kontaminan. Penambahan bahan organik ke dalam tanah yang terkontaminasi $\mathrm{Cr}$ dan menjaga $\mathrm{pH}$ tanah menjadi netral dapat menurunkan kandungan Cr terlarut. Hal ini terjadi melalui mekanisme absorpsi $\mathrm{Cr}$ oleh bahan organik maupun menginisiasi pembentukan senyawa kompleks yang tidak dapat diserap oleh tanaman.

Tanaman sendiri telah mengembangkan mekanisme yang kompleks dengan cara mengontrol penyerapan dan akumulasi logam berat (Cobbett dan Goldsbrough, 2002 cit. Panda dan Choudhury, 2005). Mekanisme ini melibatkan proses chelat dan mengisolir ionion logam dengan ikatan logam ligands tingkat tertentu yang berupa phytocelatins (PCs) dan metallothioneins (MTs) (Cobbett, 2000; Cobbett dan Goldsbrough, 2002 cit. Panda dan Choudhury, 2005). MTs kemungkinan memiliki peranan dalam detoksifikasi kromium pada tanaman dan hal itu telah dilaporkan untuk sorghum dimana MT-serupa protein muncul saat terjadi cekaman krom (Shanker et al., 2004 cit. Panda dan Choudhury, 2005). MTs adalah hasil dari translasi mRNA dan memiliki sifat seperti sistein yang kaya logam serta memiliki ikatan dengan protein yang bermolekul ringan dan rendah (Kagi, 1991 cit. Panda dan Choudhury, 2005). MTs mungkin mempunyai peranan yang sangat penting dalam detoksifikasi krom pada tanaman, kemungkinan dengan mengikat ion-ion krom dan menjadikannya kurang toksik.

\section{KESIMPULAN DAN SARAN}

\section{Kesimpulan}

1. Kromium dapat diserap oleh kedua jenis sawi pada saat fase pertumbuhan awal tanaman (panen awal) maupun saat mencapai fase pertumbuhan optimal (panen akhir).

2. Kailan menyerap kromium dalam jumlah lebih besar dibandingkan pakchoy pada semua takaran pemberian lumpur limbah.

3. Akumulasi krom di bagian perakaran tanaman lebih besar dibandingkan di bagian tajuk tanaman untuk kedua jenis sawi.

4. Sawi kailan dan pakchoy yang ditanam pada lahan yang mengandung krom dari limbah industri penyamakan kulit yang diteliti tidak dapat dikonsumsi manusia karena kandungan krom dalam jaringan tanaman bagian tajuk yang umumnya dikonsumsi melebihi ambang batas konsumsi harian sebesar $0,035 \mathrm{mg} / \mathrm{kg}$ per hari.

\section{Saran}

Tidak melakukan pembuangan lumpur limbah industri penyamakan kulit di sembarang lahan dan tidak menanami lahan tersebut dengan tanaman untuk

\section{DAFTAR PUSTAKA}

Akinci, I. E. and S. Akinci. 2010. Effect of chromium toxicity on germination and early seedling growth in melon (Cucumis melo L). African Journal of Biotechnology.9(29): 4589-4594

A n o n i m. $2010 . T a n a h$. http://id.wikipedia.org/wiki/Tanah. Diakses tanggal 4 November 2010.

Ghani, A. 2011. Effect of chromium toxicity on growth, chlorophyll and some mineral nutrients of Brassica juncea. Egypt Academic Journal Biology Science. 2(1):9-15.

Jun, R., T. Ling and Z. Guanghua. 2009. Effects of chromium on seed germination, root elongation and coleoptiles growth in six pulses. International Journal Environment Science Technology. 6(4) : 571-578. 
Masdin. 2010. Interaksi kromium dengan mikroorganisme dan tanaman. Health and Home Tips.

Meuser, H. 2012. Soil Decontamination. Soil Remediation and Rehabilitation Environmental Pollution. 23 : 201-278

Panda, S. K. and S. Choudhury. 2005. Toxic metals in plants : Chromium stress in plants. Brazilian Journal of Plant Physiology. 17 (1).

Saleh, M. H. 2007. Recovery dan Zeolit Cegah Pencemaran Logam Berat. Suara Merdeka Cyber News. Diakses 2 Maret 2009.
Shanker, A. K., C. Cervantes, H. Loza-Tavera and S. Avudainayagam. 2005. Chromium toxicity in plants. Environment International. 31 : 739753.

Schiavon, M., E. A. H. Pilon-Smits, M. Wirtz, R. Hell and M. Malagoli. 2008. Interactions between chromium and sulfur metabolism in Brassica juncea. Jurnal of Environmental Quality. 37 : 1536-1545 